\title{
DAERAH KEPULAUAN SEBAGAI SATUAN PEMERINTAHAN DAERAH YANG BERSIFAT KHUSUS
}

\author{
Kotan Y. Stefanus \\ Fakultas Hukum dan Program Pascasarjana Universitas Nusa Cendana - Kupang \\ E-mail: kotanys@ymail.com
}

\begin{abstract}
Some regions (local government) geograpically lie in islands area which get unjustice treatment compared with other regions. The problem is because of the service to public is broad and heavy in some islands, but do not get particular treatment from central government Search for and investigation about the law basis about archipelago area expresses that one of the principles of regional government undertaking according to the basic constitution of 1945 is that giving space to advance particular regions and specifically (including to as regions in islands). However, such principle has not been implicated broadly and clearly in the rule Law Number 32 years 2004.
\end{abstract}

Key words: archipelago area, local government, particular regions, Legitimacy.

\begin{abstract}
Abstrak
Sejumlah daerah (pemerintah daerah) yang berada dalam kawasan kepulauan kurang mendapatkan perlakuan yang adil dan selaras dengan daerah-daerah lainnya. Persoalan yang dihadapi adalah jangkauan pelayanan masyarakat yang demikian luas dan berat tersebar pada sejumlah pulau, namun tidak mendapatkan perlakuan khusus dari pemerintah (pusat). UUD 1945 memuat prinsip-prinsip penyelenggaraan pemerintahan daerah, antara lain memungkinkan pengembangan daerah-daerah khusus dan istimewa (termasuk daerah kepulauan), namun prinsip dimaksud belum dijabarkan secara tegas dan jelas dalam UU No. 32 Tahun 2004.
\end{abstract}

Kata kunci: daerah kepulauan, pemerintah daerah, daerah khusus, pengakuan.

\section{Pendahuluan}

Undang-undang Nomor 32 Tahun 2004 tentang Pemerintahan Daerah (selanjutnya penulis singkat menjadi UU No. 32 Tahun 2004) dan perubahannya masih mengandung sederetan masalah dalam mengelola pemerintahan daerah, terutama relasi antara pemerintah (pusat) dengan pemerintah daerah dan antara pemerintah daerah. Demikian pula dalam implementasinya, terdapat sejumlah ketimpangan yang sering mengganggu dinamika pemerintahan daerah.

Salah satu wacana yang menguat belakangan ini adalah sejumlah daerah (pemerintah daerah) yang secara geografis berada dalam kawasan kepulauan mengapresiasikan kepentingannya yang kurang mendapatkan perlakuan yang adil dan selaras dengan daerah-daerah lainnya. Persoalan yang dihadapi adalah keter- batasan kewenangan pemerintah daerah di wilayah laut, jangkauan pelayanan terhadap masyarakat yang demikian luas dan berat tersebar pada sejumlah pulau, namun tidak mendapatkan perlakuan khusus dari pemerintah (pusat) Kondisi ini menyebabkan pelayanan publik pada daerah-daerah dimaksud tidak dapat dilaksanakan secara efektif. Selain itu, daerah-daerah kepulauan dengan berbagai kekhasannya membutuhkan penyelenggaraan pemerintahan daerah berdasarkan kekhasannya, namun belum mendapatkan pengakuan untuk itu.

Realitas juga menunjukkan wilayah Indonesia terdiri dari gugusan pulau-pulau besar dan kecil yang disatukan oleh hamparan laut yang luas, terbentang dari Sabang sampai ke Merauke dan dari Miangas sampai ke Rote. ${ }^{1}$ Le-

Masalah pengelolaan ruang laut dapat menimbulkan konflik antar Negara, bahkan memicu ketegangan 
bih jauh dikatakan M. Agus Santoso bahwa wilayah Republik Indonesia begitu luas dengan bentuk pulau-pulau, namun demikian dapat dipersatukan dengan bentuk Negara Kesatuan Republik Indonesia yang dilandasi secara konstitusional dalam Pasal 1 ayat (1) UUD 1945. ${ }^{2}$ Konsekuensi dari negara Indonesia sebagai $\mathrm{Ne}$ gara Kesatuan yang bercorak Negara Kepulauan, seyogyanya berdampak pada legitimasi yuridis formal pada pengaturan lebih lanjut tentang Daerah Otonom yang berbasis kepulauan, namun sampai saat ini belum diikuti dengan penjabaran lebih lanjut di tingkat pemerintahan daerah.

Permasalahan daerah kepulauan juga menjadi penting untuk dicermati dan bahas secara serius terkait dengan sederetan realitas yang mencuat, ${ }^{3}$ diantaranya adalah pertama, secara sosiologis, ketujuh Provinsi Kepulauan mempunyai perbedaan yang spesifik dengan provinsi-provinsi lain, yaitu karakteristik yang berbeda sehingga model pembangunannya harus berbeda dengan model yang umum; manajemen administrasi pemerintahan haruslah berbasis kepulauan; pelayanan masyarakat harus diarahkan ke pulau-pulau, karena masyarakat provinsi kepulauan hidup pada pulau-pulau yang terisolir; rata-rata masyarakat pada provinsi kepulauan terlambat dalam pembangunan infrastruktur; mempunyai pulau kecil terluar yang membutuhkan pendekatan prosperity dan security secara bersamaan.

kawasan. Hal ini masih terjadi di laut China Selatan, tepatnya di Kepulauan Spartly antara RRC, Malaysia, Vietnam, Filipina dan Brunei. Begitupun di Kepulauan Sipadan dan Ligitan, antara Malaysia dan Indonesia dan persoalan perdagangan pasir antara Singapura dan Indonesia. Contoh tersebut dapat memberikan gambaran bahwa konflik pemilikan ruang laut dapat memicu ketegangan kawasan. Demikian halnya dengan wilayah laut di Indonesia mestinya diatur pengelolaan dan pemanfaatannya secara adil, sehingga tidak menimbulkan ketegangan dalam wilayah Negara Kesatuan Republik Indonesia. Lihat Rukmin Dahuri, "Kerjasama Kelautan Dalam Menciptakan Stabilitas Kawasan", J urnal PASKAL, Vol. 1 No. 3, Oktober 2002, J akarta: Pusat Kajian Strategis Kepentingan Nasional, hlm. 5.

2 M. Agus Santoso, "Otonomi Daerah di Negara Kesatuan Republik Indonesia", Jurnal IImu Administrasi, Vol. 6 No. 4, Desember 2009, hlm. 391.

Badan Kerjasama Propinsi Kepulauan, 2009, Naskah Akademik Undang Undang Daerah Kepulauan, Jakarta, hlm. 7-8.
Kedua, Alinea IV Pembukaan UUD 1945 terkait dengan tujuan Negara Kesatuan Republik Indonesia "... melindungi segenap bangsa Indonesia dan seluruh tumpah darah Indonesia dan untuk memajukan kesejahteraan umum, mencerdaskan kehidupan bangsa dan ikut melaksanakan ketertiban dunia yang berdasarkan kemerdekaan, perdamaian abadi dan keadilan sosial ...".

Ketiga, Pasal 18, Pasal 18A, Pasal 18B, Pasal 25A Undang Undang Dasar 1945. Pengaturan peraturan perundang-undangan yang berlaku sebagai hukum positif di Indonesia belum mencerminkan penjabaran dari pasal-pasal konstitusi di atas, terutama berkaitan dengan prinsip Negara Kepulauan.

Keempat, terdapat perbedaan paradigma pengalokasian anggaran Negara dalam UU No. 32 Tahun 2004 tentang Perimbangan Keuangan Antara Pemerintah Pusat dan Pemerintah Daerah. Ada pandangan yang mengabaikan faktor luas wilayah perairan (lautan) sebagai satu kesatuan wilayah, sehingga berdampak pada terhambatnya proses pembangunan dan pelayanan kepada masyarakat di daerah kepulauan. Oleh karena itu, untuk menata kehidupan bermasyarakat di wilayah geografis yang wilayah lautannya lebih besar dari daratan, secara politis diperlukan adanya legitimasi hukum mengenai kesatuan wilayah dan perlakuan khusus pada daerah kepulauan.

Kelima, apabila karakteristik Daerah Kepulauan tidak menjadi perhatian dalam kebijakan Pemerintah, maka dapat saja terjadi pelanggaran Hak Asasi Manusia, pada warga Negara maupun masyarakat yang berada pada Daerah Kepulauan. Hal ini penting karena Pasal 28H ayat (2) UUD 1945 menegaskan "Setiap orang berhak mendapat kemudahan dan perlakuan khusus untuk memperoleh kesempatan dan manfaat yang sama guna mencapai persamaan dan keadilan". Selanjutnya Pasal 281 ayat (2) menegaskan "Setiap orang berhak bebas dari perlakuan yang bersifat diskriminatif atas dasar apapun dan berhak mendapatkan perlindungan terhadap perlakuan yang bersifat diskriminatif itu". Perlakuan khusus dan penting menjadi perhatian dalam kebijakan Peme- 
rintah, sehingga tidak terkesan melakukan perlakuan yang bersifat diskriminatif baik dalam penyelenggaraan pemerintahan, pelaksanaan pembangunan maupun pelayanan kepada masyarakat.

Beranjak dari pemikiran yang telah paparkan, maka tulisan ini berusaha menggali dan mencari landasan hukum ${ }^{4}$ tentang Daerah Kepulauan, sehingga dapat memberikan kontribusi dalam proses revisi UU No. 32 Tahun 2004 yang sedang berlangsung dan pengaturan lebih lanjut satuan pemerintahan daerah sebagai konsekuensi dari pengakuan Negara Kesatuan Republik Indonesia sebagai negara kepulauan. Beberapa butir pemikiran sengaja ditawarkan untuk melakukan revisi UU No. 32 Tahun 2004 dan pembentukan Undang Undang Daerah Kepulauan, sehingga status dan posisi daerah-daerah kepulauan (Propinsi Maluku, Maluku Utara, NTT, NTB, Sulawesi Utara, Kepulauan Riau, dan Bangka Belitung) akan mendapatkan legitimasi dan justifikasi yang memadai ${ }^{5}$ dalam konteks negara kesatuan Republik Indonesia.

\section{Pembahasan \\ Karakteristik dan Permasalahan Daerah Ke- pulauan}

Daerah Kepulauan, secara umum, memiliki karakteristik akuatik terestrial (wilayah laut lebih besar dari wilayah darat), yang membedakannya dengan daerah-daerah terestrial maupun terestrial akuatik. Dalam konteks ini, ketujuh Provinsi Kepulauan yang bergabung dalam Badan Kerjasama Provinsi Kepulauan telah me-

\footnotetext{
Pada masa sekarang perundang-undangan merupakan sarana atau wadah yang paling banyak digunakan untuk merumuskan kaidah atau norma hukum dibanding dengan sumber hukum lainnya karena perundangundangan memiliki beberapa kelebihan yaitu lebih menjamin kepastian perumusan, lebih bersifat instrumental dan antisipatif. Lihat Grace J uanita, "Pengaruh Kaidah Bukan Hukum Dalam Proses Pembentukan Kaidah Hukum", J urnal Hukum Pro J ustitia, Vol. 25 No. 2, April 2007, Bandung: FH Unpar, hlm. 124.

Legitimasi lebih menekankan pengakuan empirik dari publik, sedangkan justifikasi lebih menekankan aspek legalitas. Bilamana kita menelaah secara kritis masalah legitimasi dan legalitas, maka argumentasi yang hendak diajukan adalah legalitas sebaiknya disesuaikan dengan legitimasi, situasi normatif hukum perlu mengakomodasi kenyataan empiris, dan ketentuan UU hendaknya mempertimbangkan fakta politik berupa aspirasi rakyat.
}

negaskan bahwa karakteristik Provinsi Kepulauan yang membedakannya dengan provinsi-provinsi lain dapat terlihat dari: ${ }^{6}$ Luas wilayah laut yang lebih besar dari wilayah daratan; Segi persebaran demografis, penduduk wilayah kepulauan biasanya bersifat relatif sedikit dan penyebarannya tidak merata; Segi sosial budaya, komunitas-komunitas di wilayah kepulauan tersegregasi dalam pemukiman menurut territorial suatu pulau, sehingga lasim berimplikasi pada kuatnya rasa keterikatan pada tanah (baca: pulau), pola hidup pada pulau-pulau kecil selaras dengan alam (lamban menerima perubahan); Segi ketersedian sumber daya alam, relatif beragam; Segi sistim kehidupan, ditentukan oleh tingkat isolasi geografis dengan keunikan habitat (endemis) dan keanekaragaman biotik (biodiversitas); Segi sosial ekonomi, aktivitas ekonomi, jenis dan derajat dinamika ekonomi umumnya terbatas dan berskala kecil, serta belum didukung oleh jaringan distribusi dan pemasaran secara memadai; Segi lingkungan, sumber daya lingkungan kecil, rentan terhadap perubahan (entrophy), rawan bencana alam (gelombang di permukaan laut, didominasi oleh gelombang gravitasi yang ditimbulkan oleh angin; arus laut disebabkan oleh dua faktor yakni angin musim dan pasang surut); 8) Dari segi biogeografis, terdapat potensi keanekaragaman hayati darat dan perairan sekitar pulau-pulau (kecil); 9) Hampir semua Provinsi Kepulauan berada pada wilayah/ kawasan Perbatasan Negara, yang memiliki pulau kecil terluar.

Berdasarkan Peraturan Presiden Nomor 78 Tahun 2005, maka pulau-pulau kecil terluar yang ada pada Provinsi Kepulauan dapat dirinci, Provinsi Kepulauan Riau 20 pulau, Provinsi Maluku 18 pulau, Provinsi Sulawesi Utara 12 pulau, Provinsi Nusa Tenggara Timur 5 pulau, Provinsi Nusa Tenggara Barat 1 pulau, Provinsi Maluku Utara 1 pulau dan Provinsi Kepulauan Bangka Belitung 0 pulau. Luas wilayah laut pada Daerah Provinsi dengan karakteristik akuatik terestrial (kepulauan), apabila tidak didukung oleh aturan hukum mengenai kewenangan yang

6 Badan Kerjasama Propinsi kepulauan, op.cit., hlm. 1516. 
dapat menyatukan, maka akan menyebabkan terjadinya ketimpangan dalam pengaturan dan pemanfaatan sumberdaya alam di wilayah laut maupun ketimpangan dalam penyelenggaraan pemerintahan, pelaksanaan pembangunan maupun pelayanan kepada masyarakat pada daerah kepulauan yang berbeda dengan daerah lain.

Fenomena empirik yang terlihat secara konkrit terkait dengan karakteristik daerah kepulauan di atas adalah, terbatasnya sarana dan prasarana pelayanan dasar; terbatasnya kemampuan keuangan daerah; sarana dan prasarana tranportasi laut dan udara yang sangat minim; biaya tranportasi dalam rangka pelayanan pemerintahan yang sangat mahal; terbatasnya aksesibilitas masyarakat secara umum; masih adanya isolasi fisik dan sosial; adanya ketergantungan fiskal yang sangat tinggi kepada Pemerintah; belum berkualitasnya berbagai layanan pemerintahan baik layanan publik maupun sipil; masih adanya disparitas ekonomi antar daerah; rendahnya kualitas sumberdaya manusia. ${ }^{7}$

Identifikasi permasalahan berdasarkan Pasal 13 UU No. 32 Tahun 2004 memperlihatkan sejumlah keterbatasan yang memerlukan penanganan khusus pada Daerah Kepulauan, pengendalian dan pengawasan perumusan perencanaan dan pelaksanan pembangunan daerah; perencanaan pelaksanaan pemanfaatan tata ruang; penyelenggaraan ketertiban umum dan ketenteraman masyarakat; penyediaan sarana dan prasarana umum; penanganan bidang kesehatan; penyelenggaraan pendidikan dan alokasi sumberdaya manusia; penanggulangan masalah sosial lintas kabupaten/kota; pelayanan bidang ketenagakerjaan lintas kabupaten/ kota; koordinasi dan fasilitasi pengembangan koperasi, usaha kecil dan menengah termasuk lintas kabupaten/kota; pengendalian lingkungan hidup; pelayanan pertanahan termasuk lintas kabupaten/ kota; pelayanan kependudukan; administrasi umum pemerintahan; pelayanan administrasi penanaman modal termasuk lintas kabupaten/ kota; pelayanan dasar lainnya. ${ }^{8}$

\section{Luas Lingkup dan Sifat Pemerintahan Daerah Menurut UUD 1945 (Amandemen)}

Salah satu aspek penting yang turut direformasi adalah konstitusi Indonesia. Selama orde baru, UUD 1945 dikeramatkan dan dimanfaatkan secara licik oleh penguasa untuk mempertahankan dan melanggengkan kekuasaan. Ternyata dengan tuntutan reformasi untuk mewujudkan civil society dan terciptanya good governance, maka dilakukan amandemen terhadap UUD 1945. Pada Amandemen yang kedua, telah dilakukan perubahan rumusan Pasal 18 UUD 1945 dengan rumusan terdiri dari Pasal 18, 18A, dan 18B. Bilamana dicermati pengaturan dimaksud, maka dapat dipetik beberapa prinsip penyelenggaraan pemerintahan daerah sebagai berikut.

Pertama, pemerintahan daerah terdiri dari dua tingkatan, yaitu Pemerintahan Propinsi dan Pemerintahan Kabupaten, dan Kota; kedua, penyelenggaraan pemerintahan daerah berpijak pada asas otonomi dan tugas pembantuan; ketiga, masing-masing Pemerintahan Propinsi, Kabupaten dan Kota memiliki DPRD, yang anggota-anggotanya dipilih melalui Pemilihan Umum, serta setiap Pemerintahan Propinsi, Kabupaten dan Kota dipimpin oleh Gubernur, Bupati dan Walikota yang dipilih secara demokratis; keempat, setiap Pemerintahan Daerah menjalankan otonomi seluasluasnya, kecuali ditentukan lain oleh Undang Undang mengenai urusan Pemerintah Pusat; kelima, dalam rangka melaksanakan otonomi daerah, setiap pemerintahan daerah berhak menetapkan peraturan daerah dan peraturanperaturan lainnya; keenam, hubungan wewenang antara pemerintah pusat dan pemerintahan daerah propinsi, kabupaten, dan kota memperhatikan kekhususan dan keragaman daerah; ketujuh, hubungan keuangan, pelayanan umum, pemanfaatan sumber daya alam dan sumber daya lainnya antara pemerintah pusat dan pemerintahan daerah diatur dan dilaksanakan secara adil dan selaras berdasarkan undangundang; kedelapan, satuan-satuan pemerintahan daerah yang bersifat khusus atau bersifat istimewa diakui dan dihormati. Juga diakui dan dihormati kesatuan-kesatuan masyarakat hu- 
kum adat beserta hak-hak tradisionalnya sepanjang masih hidup dan sesuai dengan pekerbangan masyarakat dan prinsip Negara Kesatuan Republik Indonesia, yang diatur dalam undang-undang.

Pertanyaan yang muncul kemudian adalah apakah satuan-satuan pemerintahan daerah yang bersifat khusus dan istimewa memiliki tingkatan pemerintahan yang sejajar dengan pemerintahan Propinsi, Kabupaten dan Kota ataukah terlepas dari satuan pemerintahan yang ada? Apabila dicermati prinsip pemerintahan daerah terdiri dari dua tingkatan, yaitu pemerintahan propinsi dan pemerintahan kabupaten/ kota, dihubungkan dengan prinsip satuan-satuan pemerintahan daerah yang bersifat khusus atau istimewa diakui dan dihormat, serta prinsip hubungan wewenang antara pemerintah pusat dan pemerintahan daerah propinsi, kabupaten/kota memperhatikan kekhususan dan keragaman daerah, maka dapat dideskripsikan struktur pemerintahan daerah berdasarkan luas tingkatan pemerintahan daerah dan kekhususan atau keistimewaan pemerintahan daerah sebagai berikut: pemerintahan tingkat propinsi yang khusus atau istiwema; pemerintahan tingkat kabupaten/kota yang khusus atau istimewa

Konstruksi pemerintahan daerah ini tidak diatur lebih jauh dalam UUD 1945 (amandemen) dan semakin kabur ketika status Penjelasan UUD 1945 menjadi goyah sebagai akibat amandemen UUD 1945, maka perlu diatur lebih lanjut dalam Undang Undang Pemerintahan Daerah, dengan memperjelas kriteria/tolok ukur kekhususan atau keistimewaan pemerintahan daerah dan bagaimana bentuk perlakuan terhadap kekhususan dan keistimewaan pemerintahan daerah dimaksud (wujud dari prinsip hubungan wewenang antara pemerintah pusat dan pemerintahan daerah propinsi, kabupaten, dan kota memperhatikan kekhususan dan keragaman daerah). Oleh karenanya, salah satu hal yang perlu dipertimbangkan dalam perubahan UU No. 32 Tahun 2004 adalah memasukkan Propinsi dan Kabupaten Kepulauan sebagai salah satu bentuk kekhususan pemerintahan daerah dan memperjelas bentuk dan luas per- lakuan pemerintah terhadap kekhususan dan keistimewaan pemerintahan daerah dimaksud.

Perlakuan pemerintah terhadap kekhususan dan keistimewaan pemerintahan daerah diperlukan sejalan dengan eksistensi Indonesia sebagai Negara Kesatuan. Dalam Negara kesatuan, semua kekuasaan pemerintahan ada di tangan pemerintah (pusat). Kekuasaan terletak pada pemerintah pusat dan tidak ada pada pemerintah daerah. Pemerintah pusat mempunyai wewenang untuk menyerahkan sebagian kekuasaannya kepada daerah berdasarkan hak otonomi, tetapi pada tahap terakhir kekuasaan tertinggi tetap di tangan pemerintah pusat.

Pemikiran yang dipaparkan di atas hendak menegaskan bahwa prinsip yang dianut dalam Negara kesatuan ialah kewenangan pemerintah (pusat) untuk campur tangan yang lebih intensif terhadap persoalan-persoalan di daerah, tetapi kewenangan dimaksud terdapat dalam suatu pengaturan yang jelas dan tegas. Pada prinsipnya pemerintah (pusat) dapat mencampuri urusan apapun juga sepanjang mengenai kepentingan umum. Dengan demikian dapatlah dikatakan bahwa ruang intervensi pemerintah (pusat) terhadap pemerintahan daerah (Propinsi dan Kabupaten/Kota) memiliki legitimasi dalam konteks Indonesia sebagai negara kesatuan.

Legitimasi intervensi pemerintah (pusat) tersebut juga ditujukan kepada Propinsi atau kabupaten Kepulauan sebagai wujud dari kekhususan dan keistimewaan pemerintahan daerah. Bentuk dan luas intervensi pemerintah (pusat) dimaksud mestinya diatur dalam Undangundang Pemerintahan Daerah. Oleh karena itu, dalam perubahan Undang-undang Pemeritahan Daerah perlu dipertegas dan diperjelas pengaturan tentang daerah istimewa dan daerah khusus, dengan merumuskan kriteria daerah khusus dan daerah istimewa, serta menentukan luas perlakuan/ intervensi pemerintah terhadap daerah-daerah dimaksud. Hal yang perlu dipertimbangkan adalah daerah-daerah yang secara geografis mengalami hambatan seperti daerah terpencil, daerah tertinggal, daerah pesisir dan kepulauan. Seyogyanya dalam UU Pemerintahan Daerah diberikan ruang kepada setiap Propinsi 
dan Kabupaten/Kota untuk mengatur kekhususan dan keistimewaannya, dengan titik berat kepada daerah tertinggal, daerah terpencil, daerah pesisir/kepulauan, dan daerah yang beresiko terhadap bencana.

Pemikiran mengenai pengakuan kekhususan daerah kepulauan (atau wacana lain tentang pengakuan daerah-daerah yang bersifat istimewa) dimaksud sesungguhnya memiliki wacana akademik sebagaimana dikemukakan Charles D. Tarlton yang disetir Robert Endi Jaweng. ${ }^{9}$ Dalam pandangan Tarlton, model desentralisasi teridentifikasi dalam desentralisasi simetris dan desentralisasi asimetris. Model desentralisasi simetris/ biasa ditandai kesesuaian (conformity) dan keumuman (commonality) dalam hubungan daerah dengan sistem politik nasional, pemerintah pusat maupun antar daerah. Model desentralisasi asimetris dengan ciri sebaliknya, artinya suatu daerah khusus/ istimewa memiliki pola hubungan berbeda dan tak lazim terjadi di daerah-daerah lain, utamanya hal ihwal relasi dengan pusat, relasi dengan daerah sekitar, dan pengaturan internal daerah itu sendiri.

Lebih lanjut mengenai letak kekhususan dan keistimewaan suatu daerah, Tarlton menandaskan bahwa subyek utamanya adalah soal kewenangan. Dasar pemberian dan isi kewenangan khusus/istimewa mempresentasikan alas an-alasan unik. Subyek kewenangan inilah yang nantinya menentukan bangunan relasi daerah khusus/istimewa dengan pusat atau daerah lain maupun arah kebijakan internal dan tata kelola pemerintahannya. ${ }^{10}$ Dasar Alasan memberlakukan desentralisasi asimetris pada sebagian Negara adalah bertolak dari political reason seperti respons atas keberagaman karakter regional atau primordial, bahkan ketegangan etnis (seperti kasus Quebeck di Kanada); sebagian lain dilandasi efficiency reasons, yakni bertujuan untuk penguatan ka-

\footnotetext{
Robert Endi Jaweng, "Anomali Desentralisasi Asimetris", Suara Pembaruan, Selasa, 21 Desember 2010, hIm. 5.

10 lbid.
}

pasitas pemerintah daerah dan administrasi pemerintahan. ${ }^{11}$

Berdasarkan uraian tersebut di atas, maka jelas bahwa pengakuan daerah kepulauan sebagai model pemerintahan daerah yang bersifat khusus juga memiliki rujukan akademik yaitu sebagai wujud model desentralisasi asimetris yang berlandaskan pada political reasons (keberagaman karakter regional) dan efficiency reason, yakni bertujuan untuk penguatan kapasitas pemerintah daerah. Oleh karenanya, pembentukan daerah kepulauan sebagai daerah yang bersifat khusus di Negara kesatuan Republik Indonesia memiliki landasan konstitusional dan landasan akademik yang tak perlu diragukan lagi.

Persoalan yang muncul berikutnya adalah dimanakah letak kekhususan daerah kepulauan dimaksud?. Sebagaimana dikemukakan dalam ulasan sebelumnya bahwa letak kekhususan daerah kepulauan adalah daerah kepulauan di berikan kewenangan luas terhadap wilayah laut yang berada dalam wilayah administratifnya. Kekhususan dimaksud merupakan harapan daerah kepulauan karena selama ini (menurut Pasal 18 UU No. 32 Tahun 2004), daerah diberikan wewenang pengelolaan sumberdaya laut di wilayah laut paling jauh 12 (dua belas) mil laut diukur dari garis pantai ke arah laut lepas dan/ atau ke arah perairan kepulauan untuk propinsi dan $1 / 3$ (sepertiga) dari wilayah kewenangan propinsi untuk kabupaten/ kota.

Pengakuan otonomi khusus bagi daerah kepulauan sesungguhnya bermaksud memberikan peluang bagi daerah-daerah kepulauan untuk dapat mengembangkan dan mengelola semua potensi wilayah laut secara maksimal untuk mendongkrak tingkat kesejahteraan masyarakat. Hasil penelitian Yoseph M. Laynurak mengungkapkan bahwa kesejahteraan masyarakat (khususnya nelayan) ditentukan juga oleh factor pengelolaan potensi laut dan laut secara intensif. ${ }^{12}$ Oleh karenanya, pemberian kewenangan kepada daerah-daerah kepulauan sebagai

11 Ibid.

12 Yoseph M. Laynurak, "Analisis Model Optimalisasi Sumber Daya Pantai Terhadap Kesejahteraan Nelayan di Kabupaten Belu - NTT", J urnal Litbang NTT, Flobamora, Vol. No. 01 Tahun 2009, hlm. 56. 
wujud otonomi khusus merupakan alternative untuk memberikan kesempatan kepada Pemerintah daerah untuk peningkatan kesejahteraan rakyat. Kewenangan dimaksud dapat dijelaskan di bawah ini.

Pertama, wilayah laut daerah kepulauan, mempunyai kewenangan yaitu batas daerah kepulauan di wilayah laut merupakan ruang pelaksanaan kewenangan daerah kepulauan dalam rangka pengelolaan dan pemanfaatan sumberdaya alam di laut; batas kewenangan daerah provinsi kepulauan di wilayah laut sejauh 12 (dua belas) mi laut diukur dari garis yang menghubungkan titik-titik terluar dari pulau-pulau atau karang terluar suatu daerah kepulauan ke arah laut lepas atau perairan kepulauan; apabila wilayah laut antara 2 (dua) provinsi kurang dari 24 (dua puluh empat) mil laut, kewenangan untuk mengelola dan memanfaatkan sumberdaya alam di wilayah laut dibagi sama jaraknya atau diukur sesuai prinsip garis tengah dari wilayah antar dua provinsi tersebut. Batas kewenangan daerah kabupaten/ kota kepulauan di wilayah laut sejauh maksimal 6 (enam) mil laut diukur dari garis yang menghubungkan titik-titik terluar dari pulau dan/atau karang terluar dari daerah kabupaten/ kota kepulauan, yang ditetapkan dalam Peraturan Daerah Provinsi; Dalam wilayah kewenangan daerah kabupaten/ kota kepulauan di laut, dapat ditetapkan wilayah kewenangan kesatuan masyarakat hukum adat yang tidak boleh kurang dari 1,5 (satu koma lima) mil laut diukur dari garis air rendah kearah laut lepas atau perairan kepulauan dan diatur dalam Peraturan Daerah Kabupaten/ Kota; Penetapan batas kewenangan daerah di wilayah laut, tetap menghormati hak-hak penangkapan ikan yang secara tradisional telah berlangsung.

Kedua, Kewenangan Daerah Kepulauan di laut yang terdiri dari daerah kepulauan diberikan kewenangan untuk mengelola dan memanfaatkan sumberdaya alam di wilayah laut, baik di bawah dasar dan atau di dasar laut dan atau perairan di atasnya; daerah Kepulauan mendapatkan bagi hasil atas pengelolaan sumberdaya alam di laut, baik di bawah dasar dan atau di dasar laut dan atau perairan di atasnya sesuai dengan peraturan perundang-undangan; Kewenangan daerah kepulauan untuk melakukan pengelolaan dan pemanfaatan sumberdaya alam di laut meliputi: eksplorasi, eksploitasi, konservasi, pengelolaan dan pemanfaatan kekayaan laut; pengaturan administratif; pengaturan tata ruang; penegakan hukum terhadap peraturan yang dikeluarkan oleh daerah atau yang dilimpahkan kewenangannya oleh Pemerintah; ikut serta dalam pemeliharaan keamanan; dan ikut serta dalam pertahanan dan keamanan Negara; selain itu, Pemerintah dan pemerintahan daerah melakukan kadasterisasi wilayah laut untuk mewujudkan kepastian hukum dalam pengelolaan dan pemanfaatan sumberdaya alam di laut.

\section{Hubungan keuangan, pelayanan umum, pemanfaatan sumber daya alam dan sumber daya lainnya antara pemerintah pusat dan pemerintah daerah}

Prinsip penyelenggaraan pemerintahan daerah lainnya yang ditarik dari pengaturan UUD 1945 (amandemen) adalah hubungan keuangan, pelayanan umum, pemanfaatan sumber daya alam dan sumber daya lainnya antara pemerintah pusat dan pemerintahan daerah diatur dan dilaksanakan secara adil dan selaras berdasarkan Undang Undang. Prinsip ini semestinya diwujudkan dalam pengaturan Undang Undang Pemerintahan Daerah, terutama berkaitan dengan pengaturan hubungan Pemerintah dan Pemerintah Daerah, namun justru pengaturan tentang hal tersebut belum dirumuskan secara jelas. UU No. 32 Tahun 2004 memberikan perhatian dalam pengaturan tentang hubungan kewenangan pemerintah (pusat) dengan pemerintah daerah.

Konstruksi hubungan pemerintah dengan pemerintah daerah, dikemukakan Mohammad Fauzan sebagai berikut: Pertama, suatu pembagian kekuasaan yang rasional di antara tingkat-tingkat pemerintahan dalam memungut dan membelanjakan sumber dana pemerintah, yaitu suatu pembagian yang sesuai dengan pola umum desentralisasi; kedua, suatu bagian dari sumber-sumber dana secara keseluruhan untuk membiayai fungsi, penyediaan pelayanan, dan 
pembangunan yang diselenggarakan oleh pemerintah daerah; ketiga, pembagian yang adil di antara daerah-daerah atas pengeluaran pemerintah, atau sekurang-kurangnya ada perkembangan yang memang diusahakan ke arah itu; keempat, suatu upaya perpajakan (fiscal effort) dalam memungut pajak dan retribusi oleh pemerintah daerah yang sesuai dengan pembagian yang adil atas beban keseluruhan dari pengeluaran pemerintah dalam masyarakat. ${ }^{13}$

Berdasarkan pemahaman tentang konstruksi hubungan pemerintah dan pemerintah daerah, maka hubungan keuangan, pelayanan umum, pemanfaatan sumber daya alam dan sumber daya lainnya antara pemerintah pusat dan pemerintah daerah harus diatur secara adil dan selaras. Pengaturan yang adil dan selaras tentunya mempertimbangkan berbagai aspek terkait, termasuk aspek kondisi geografis dan realitas masyarakat yang hidup dalam satu tatanan pemerintahan daerah, namun berada di pulau-pulau yang tersebar atau sering disebut sebagai daerah (propinsi atau kabupaten kepulauan). Penegasan ini harus mendapat perhatian khusus dalam pengaturan hubungan pemerintah dan pemerintah daerah seiring dengan gagasan untuk merevisi UU No. 32 Tahun 2004.

Berkaitan dengan hubungan pemerintah dan pemerintah daerah dalam hal pemanfaatan sumber daya alam dan sumber daya lainnya, tentunya merujuk pada ketentuan Pasal 33 ayat (3) UUD 1945, yaitu "bumi air dan kekayaan alam yang terkandung di dalamnya dikuasai oleh Negara dan dipergunakan sebesar-besar kemakmuran rakyat". Pengertian dikuasai Negara menurut pendapat Mahkamah Konstitusi bahwa tidak dapat diartikan hanya sebatas hak untuk mengatur dan mengawasi, karena hal tersebut dengan sendirinya melekat dalam fungsi-fungsi Negara tanpa harus menyebut secara khusus dalam UUD 1945, dan sekiranya pun tidak dicantumkan dalam konstitusi sebagaimana lazim di banyak Negara yang menganut paham ekonomi liberal, sudah dengan sendiri-

13 Muhammad Fauzan, 2006, Hukum Pemerintahan Daerah, Kajian tentang Hubungan Keuangan Antara Pusat dan Daerah, Yogyakarta: UII Press, hlm. 34. nya Negara berhak mengatur perekonomian. Atas dasar itu, Mahkamah Konstitusi berpendapat bahwa penguasaan Negara diartikan dari konsepsi kedaulatan rakyat Indonesia atas segala sumber kekayaan "bumi dan air dan kekayaan alam yang terkandung di dalamnya", sebagai pemilikan publik oleh kolektivitas rakyat atas sumber-sumber kekayaan, dan kemudian rakyat tersebut secara kolektivitas dikonstruksikan oleh UUD 1945 memberikan mandate kepada Negara untuk mengadakan kebijakan (beleid), tindakan pengurusan (bestuursdaad), pengaturan (regelendaad), pengelolaan (bestuursdaad) dengan kewenangannya untuk mengeluarkan dan mencabut fasilitas ijin, lisensi, dan konsesi. ${ }^{14}$ Lebih lanjut Abrar Saleng ${ }^{15}$ mengemukakan bahwa penggunaan Pasal 33 ayat (3) UUD 1945 dilakukan dengan pendekatan bahwa sumberdaya alam dikuasai oleh negara dan merupakan milik bersama (common property) bangsa-bangsa (nation) yang ada di Indonesia dan digunakan untuk kesejahteraan dan sebesar-besarnya kemakmuran rakyat dari satu generasi ke generasi selanjutnya (intergeneration) secara berkelanjutan (substainablility).

Era otonomi daerah telah membawa perubahan yang mendasar dalam sistem dan praktik pengelolaan sumberdaya alam. Perubahan dimaksud terlihat dalam kewenangan pemerintah daerah yang besar dalam pengelolaan sumberdaya alam. Sejalan dengan itu, Kusnaka Adimihardja menandaskan bahwa strategi pengelolaan sumber daya alam yang bersifat makro selama ini seyogyanya beralih ke model pengelolaan yang bersifat mikro dengan mempertimbangkan keragaman budaya masyarakat. ${ }^{16}$ Itu berarti, ruang pengelolaan sumber daya alam mestinya diberikan lebih besar kepada pemerintah daerah karena pemerintah

14 Maruarar Siahaan, "Relevansi Penguasaan Negara atas Cabang Produksi Strategis Menurut UUD 1945", J urnal Konstitusi, Vol. 4 No. 3, September 2007, Jakarta: MKRI, hlm. 21-22.

15 Abrar Saleng, "Implementasi Bentuk Negara Kesatuan Dalam Pengelolaan Sumber Daya Alam Dan Kekayaan Negara Dari Perspektif Otonomi Daerah", J urnal Hukum Yurisprudensia, Vol. 6 No. 1, J anuari 2007, hlm. 52.

16 Kusnaka Adimihardja, "Kearifan Lokal kumunitas Adat Mengelola Sumber Agraria", J urnal Analisis Sosial, Vol. 6 No. 2, J uli 2001, hlm. 85. 
daerah lebih menguasai realitas kehidupan masyarakat dan keragaman budaya di daerahnya dan lebih terbuka ruang untuk pengelolaan sumber daya alam secara demokratis. ${ }^{17}$ UU No. 32 Tahun 2004 tentang Pemerintahan Daerah menentukan bahwa "Daerah berwenang mengeIola sumberdaya nasional yang tersedia di wilayahnya dan bertanggungjawab memelihara kelestarian lingkungan sesuai dengan peraturan perundang-undangan" (Pasal 17). ${ }^{18}$

Pemaknaan terhadap hak penguasaan Negara ini dapat juga diterapkan pada tingkat daerah dalam Negara Kesatuan Republik Indonesia sepanjang didelegasikan kepada daerah dengan pemberlakuan asas desentralisasi. Oleh karenanya, dalam era otonomi daerah yang antara lain ditandai dengan tuntutan untuk pengakuan daerah kepulauan sebagai salah satu bentuk otonomi khusus, kewenangan pengelolaan sumberdaya laut dan kepulauan secara luas juga merupakan sesuatu hal yang melekat dengan otonomi khusus dimaksud.

\section{Asas Penyelenggaraan Urusan Pemerintahan Berdasarkan Asas eksternalitas}

UU No. 32 Tahun 2004 menegaskan bahwa pemerintah daerah menyelenggarakan urusan pemerintahan yang menjadi kewenangannya, kecuali urusan pemerintahan yang oleh Undang Undang ini ditentukan menjadi urusan pemerintah. Dengan ketentuan tersebut, pemerintah daerah kabupaten atau kota tidak mencakup kewenangan dalam seluruh bidang pemerintahan, tetapi terbatas pada urusan yang menjadi wewenangnya. Hal inilah yang menjadi fenomena adanya pengurangan kewenangan atau pengambilalihan kewenangan pemerintahan daerah kabupaten/kota yang sebelumnya begitu luas. Dengan kata lain, sekarang tidak

17 Kotan Y. Stefanus, "Mengembangkan Demokrasi Dalam Era Otonomi Daerah", J urnal Konstitusi, Vol. 2 No. 2, Nopember 2009, Jakarta: MKRI, hlm. 19. Spirit reformasi yang telah bergulir sepuluh tahun lebih belum merasuki sendi-sendi system politik dan belum menegaskan demokrasi sebagai prinsip ketatanegaraan di Indonesia.

18 Penjelasan Terhadap Pasal 17 Undang Undang Nomor 32 Tahun 2004, yang dimaksud dengan sumberdaya nasional adalam sumberdaya alam, sumberdaya buatan dan sumberdaya manusia. berlaku lagi adanya otonomi seluas-luasnya sebagaimana diatur UU No. 22 Tahun 1999.

Pembagian urusan pemerintahan terdiri dari dua jenis urusan pemerintahan, yaitu: pertama, urusan pemerintahan yang merupakan wewenang sepenuhnya pemerintah (pusat); dan kedua, urusan pemerintahan yang bersifat concurrent, yaitu penanganannya dalam bagian atau bidang tertentu dapat dilaksanakan bersama antara pemerintah (pusat) dan pemerintah daerah. Dengan demikian, setiap urusan yang bersifat concurent senantiasa ada bagian urusan yang menjadi kewenangan pemerintah pusat dan ada bagian yang diserahkan kepada propinsi dan ada juga urusan pemerintahan yang diserahkan kepada kabupaten/ kota.

Pembagian kewenangan yang concurrent secara proporsional antara pemerintah (pusat), pemerintah propinsi, dan pemerintah kabupaten/kota, diwujudkan dengan menggunakan tiga kriteria, yaitu eksternalitas, akuntabilitas, dan efisiensi. Pelaksanaan kriteria tersebut juga harus memperhatikan keserasian hubungan antar susunan pemerintahan.

Kajian ini perlu dicermati secara kritis mengenai kriteria eksternalitas. Kriteria eksternalitas adalah penyelenggaraan suatu urusan pemerintahan yang ditentukan berdasarkan luas, besaran, dan jangkauan dampak yang timbul akibat penyelenggaraan suatu urusan pemerintahan (Penjelasan Terhadap Pasal 11 UU No. 32 Tahun 2004). Itu berarti bahwa urusan pemerintahan daerah tidak mutlak dilaksanakan oleh tingkatan pemerintahan tertentu saja, tetapi harus mempertimbangkan luas, jangkauan dan dampak yang ditimbulkan akibat penyelenggaraan suatu urusan pemerintahan daerah.

Penyelenggaraan pemerintahan di daerah-daerah (Propinsi dan Kabupaten) Kepulauan akan memiliki karakter yang berbeda dengan daerah-daerah lainnya, terutama berkaitan dengan luas, jangkauan dan dampak yang ditimbulkan. Masalah-masalah yang muncul dalam penyelenggaraan pemerintahan di daerahdaerah yang berkarakter kepulauan tentunya tidak mesti menjadi tanggungjawab daerah (Propinsi dan Kabupaten) itu semata, tetapi 
juga dapat menjadi tanggungjawab pemerintah. Intervensi pemerintah terhadap penyelenggaraan pemerintahan di daerah-daerah kepulauan mestinya mendapat perhatian khusus, sehingga dapat menyelesaikan masalahmasalah yang mencuat dan mempercepat proses menuju terwujudnya kesejahteraan rakyat. Oleh karenanya, perlu penegasan pengaturan dalam perubahan UU No. 32 Tahun 2004 mengenai kewajiban pemerintah untuk memfasilitasi penyelenggaraan pemerintahan di daerahdaerah kepulauan, namun juga tetap memberikan ruang untuk pengembangan demokrasi lokal sesuai dengan karakteristik daerah kepulauan tersebut. ${ }^{19} \mathrm{Hal}$ ini penting karena menurut $\mathrm{Hj}$. Ellydar Chaidir ${ }^{20}$ bahwa proses pembangunan hukum dapat dimulai dari penggalian nilai dan aspirasi yang berkembang dalam masyarakat oleh penyelenggara pemerintah yang berwenang merumuskan kebijakan.

\section{Landasan Hukum Daerah Khusus Kepulauan}

Beranjak dari paparan sebelumnya, maka dapatlah ditegaskan bahwa salah satu wujud dari otonomi khusus dalam Negara Kesatuan Republik Indonesia adalah Daerah Kepulauan. Eksistensi Daerah Kepulauan dimaksud sesungguhnya telah memiliki beberapa landasan yuridis dalam sistem hukum Indonesia. ${ }^{21}$

Pertama, UUD 1945. Ada sejumlah pasal dalam Undang Undang Dasar 1945 yang dapat dijadikan sebagai landasan yuridis Provinsi Kepulauan, yaitu (1) Pasal 18 A ayat (1) UUD 1945 bahwa, "hubungan wewenang antara pemerintah pusat dan pemerintah daerah provinsi, kabupaten, dan kota, atau antara provinsi dan kabupaten dan kota, diatur dengan undang undang dengan memperhatikan kekhususan dan

19 J uni Thamrin, "Menciptakan Ruang Baru Bagi Demokrasi Partisipatif: Dinamika dan Tantangan", J urnal Analisis Sosial, Vol. 9 No. 3, Desember 2004, hlm. 20. Partisipasi mendorong seluruh masyarakat sipil untuk menciptakan sinerji dan kemitraan dengan pemerintah. Partisipasi masyarakat sebenarnya membawa serta prinsip hak asasi manusia untuk mendapatkan kesempatan melakukan ekspresi diri.

20 Ellyadar Chaidir, "Manajemen Pembangunan Hukum di Daerah", Jurnal Mahkamah, Vol. 19 No. 2, Oktober 2007, hlm. 165.

21 H.M. Laica Marzuki, "Membangun Undang Undang Yang Ideal", J urnal Legislasi Indonesia, Vol. 4 No. 2, Juni 2007, J akarta: Dirjen Hukum dan HAM, hlm.4; keragaman daerah." Kekhususan dan keragaman daerah sebagaimana dimaksudkan di atas seyogyanya juga mengandung pengertian tentang kekhususan dan keragaman Daerah Kepulauan; (2) Pasal 18A ayat (2) menentukan bahwa, "hubungan keuangan, pelayanan umum, pemanfaatan sumber daya alam dan sumber daya lainnya antara pemerintah pusat dan pemerintahan daerah diatur dan dilaksanakan secara adil dan selaras berdasarkan undangundang". Salah satu hubungan pemerintah pusat dan pemerintah daerah yang harus diperhatikan adalah pemanfaatan sumberdaya alam laut pada daerah-daerah kepulauan. Pengakuan pemerintah pusat terhadap kewenangan dan pemanfaatan sumberdaya dimaksud diarahkan pada upaya mensejahterakan rakyat di kawasan tersebut dengan tetap mempertimbangkan aspek keadilan dan keselarasan. Hal ini berkonsekuensi juga pada pengakuan otonomi khusus Daerah Kepulauan; (3) Pasal 18 B ayat (1) Undang Undang Dasar 1945 menegaskan bahwa, "Negara mengakui dan menghormati satuansatuan pemerintahan daerah yang bersifat khusus atau bersifat istimewa yang diatur dengan Undang Undang". Pengakuan tentang bersifat khusus atau bersifat istimewa tersebut belum dijabarkan lebih rinci sebagai acuan untuk pembentukan daerah yang bersifat istimewa dan khusus; (4), Pasal 25A Undang Undang Dasar 1945 menegaskan bahwa, "Negara Kesatuan Republik Indonesia adalah sebuah Negara Kepulauan yang berciri Nusantara dengan wilayah dan batas-batas dan hak-haknya ditetapkan dengan undang undang." Ketentuan ini menunjukkan realitas bahwa, wilayah Indonesia terdiri dari gugusan pulau-pulau besar dan gugusan pulau-pulau kecil yang disatukan oleh hamparan laut yang sangat luas, yang terbentang dari Sabang sampai ke Merauku dan dari Miangas sampai ke Rote. Konsekwensi dari legitimasi negara Indonesia sebagai Negara Kepulauan seyogyanya mendampak juga kepada legitimasi yuridis formal kepada daerah Kepulauan sebagai daerah yang memiliki otonomi khusus; (5), Pasal 33 ayat (3) Undang Undang Dasar 1945 menegaskan bahwa, "Bumi dan air dan kekayaan alam yang terkandung di dalamnya dikuasai 
oleh negara dan dipergunakan untuk sebesarbesarnya kemakmuran rakyat." Hal ini berarti, Negara diharuskan untuk bersikap bijak dalam mengatur kekayaan alam yang ada sehingga semua masyarakat Indonesia, baik yang berdomisili di wilayah daratan dan wilayah kepulauan harus memanfaatkannya secara optimal untuk peningkatan kesejahteraan jasmani dan rohaninya; (6) Pasal 28A-28j Undang Undang Dasar 1945 mengatur tentang Hak Asasi Manusia. Secara eksplisit, perjuangan untuk mengakomodasi Provinsi Kepulauan dalam Perubahan Undang Undang Nomor 32 Tahun 2004 tentang Pemerintahan Daerah dan pembentukan rancangan Undang Undang daerah Kepulauan bermuara pada terakomodasinya Hak Asasi Manusia sebagaimana termaktub dalam Pasal 28C ayat (1) yang menentukan bahwa: "Setiap orang berhak mengembangkan diri melalui pemenuhan kebutuhan dasarnya, berhak mendapatkan pendidikan dan memperoleh manfaat dari ilmu pengetahuan dan teknologi, seni dan budaya, demi meningkatkan kualitas hidupnya dan demi kesejahteraan umat manusia". Pada Ayat (2) menentukan bahwa: "Setiap orang berhak memajukan dirinya dalam memperjuangkan haknya secara kolektif untuk membangun masyarakat, bangsa, dan negaranya". Sedangkan pada Pasal $28 \mathrm{H}$ ayat (1) menentukan bahwa: "Setiap orang berhak hidup sejahtera lahir dan batin, bertempat tinggal, dan mendapatkan lingkungan hidup yang baik dan sehat serta berhak memperoleh pelayanan kesehatan; Ayat (3): Setiap orang berhak atas jaminan sosial yang memungkinkan pengembangan dirinya secara utuh sebagai manusia yang bermartabat.

Kedua, Undang Undang Nomor 17 Tahun 1985. Undang-undang Nomor 17 Tahun 1985 tentang Pengesahan United Nation Convention on The Law of The Sea 1982 (UNCLOS) pada dasarnya harus mendapat perhatian dalam pengaturan pemerintahan daerah terkait dengan penetapan kewenangan daerah otonom pada wilayah laut. Salah satu yang diatur dalam UNCLOS 1982 adalah prinsip Negara Kepulauan (archipelagic states) dan perairan negara-negara demikian yang diperjuangkan oleh Indonesia sejak Deklarasi Djuanda 1957.
Negara Kepulauan menurut UNCLOS adalah, "suatu negara yang seluruhnya terdiri dari satu atau lebih kepulauan dan dapat mencakup pulau-pulau lain," (Pasal 46 ayat 1). Wujud suatu Negara Kepulauan ditentukan berdasarkan penentuan garis pangkal lurus kepulauan (Archipelagic Straight baseline) sebagaimana ditegaskan dalam Pasal 47 ayat (1) Konvensi Hukum Laut 1982: "Suatu Negara Kepulauan dapat menarik garis pangkal lurus kepulauan yang menghubungkan titik terluar pulau-pulau dan karang kering terluar kepulauan itu, dengan ketentuan bahwa di dalam garis pangkal demikian termasuk pulau-pulau utama dan suatu daerah dimana perbandingan antara daerah perairan dan daerah daratan, termasuk atol, adalah antara satu berbanding satu dan sembilan berbanding satu".

Penarikan garis pangkal lurus kepulauan di atas dilakukan bagi Negara dengan karakteristik kepulauan. Ketentuan tersebut tidak menjadikan penarikan garis-garis pangkal lurus kepulauan sebagai suatu kewajiban, melainkan hanya sebagai suatu pilihan. Negara Kepulauan mempunyai kebebasan untuk menetapkan cara penarikan garis pangkal lain sepanjang tidak bertentangan dengan Konvensi PBB tentang Hukum Laut tanggal 10 Desember 1982. Garis pangkal lain dalam konteks ini, pada dasarnya diberlakukan pada negara yang tidak memiliki karakteristik kepulauan yaitu penarikan garis pangkal biasa (normal baseline) atau garis pangkal lurus (straight baseline) sebagaimana dimaksud pada Pasal 5 dan Pasal 7 ayat (1) Konvensi Hukum Laut 1982. Pasal 5 menegaskan bahwa, "kecuali ditentukan lain dalam Konvensi ini, garis pangkal biasa untuk mengukur lebar laut teritorial adalah garis air rendah sepanjang pantai sebagaimana terlihat pada peta skala besar yang diakui resmi oleh negara pantai tersebut." Sedangkan Pasal 7 ayat (1) menegaskan bahwa "Di tempat-tempat di mana garis pantai menjorok jauh ke dalam dan menikung ke dalam atau jika terdapat suatu deretan pulau sepanjang pantai di dekatnya, cara penarikan garis pangkal lurus yang menghubungkan titik-titik yang tepat dapat digunakan 
dalam menarik garis pangkal dari mana lebar laut teritorial diukur".

Pasal 3-7 Konvensi PBB tentang Hukum Laut tanggal 10 Desember 1982 tersebut di atas, juga mengatur tentang batas laut teritorial tidak melebihi 12 mil laut diukur dari garis pangkal. Maksud dengan garis pangkal biasa (normal) adalah garis pangkal yang ditarik pada pantai pada waktu air laut surut dengan mengikuti lekukan-lekukan pantai. Namun demikian, dalam hal kepulauan yang terletak pada atol-atol atau kepulauan yang mempunyai karang-karang di sekitarnya, garis pangkal itu adalah garis pasang surut pada sisi karang ke arah laut sebagaimana yang ditunjukkan oleh tanda yang jelas pada peta-peta yang secara resmi diakui oleh negara pantai.

Garis pangkal lurus dapat dipakai sesuai dengan keadaan-keadaan yang diuraikan dalam Pasal 7 (bandingkan dengan Pasal 4 dari Konvensi 1958), yang sebegitu jauh merupakan perwujudan prinsip-prinsip yang diakui dalam Anglo-Norwegian Fisheries Case. Garis-garis demikian yang menghubungkan "titik-titik yang tepat" dapat ditarik untuk "tempat-tempat" di mana garis pantai menjorok ke dalam dan menikung ke dalam atau apabila terdapat suatu deretan pulau sepanjang pantai di dekatnya. Dalam Konvensi Hukum Laut di Jenewa tahun 1958, ternyata Garis Pangkal Lurus ini dikukuhkan sebagai salah satu Garis Pangkal yang dapat diterapkan dalam pengukuran lebar laut teritorial, di samping ini garis pangkal normal. Hal ini dimuat dalam Pasal 4-5 Konvensi tentang Laut Teritorial dan Zona Tambahan. Dengan isi dan jiwa yang sama seperti Konvensi J enewa 1958 tersebut, dalam Konvensi Hukum Laut 1982, Garis Pangkal Lurus inipun juga masih tetap diakui sebagai salah satu Garis Pangkal dalam pengukuran lebar Laut Teritorial (Pasal 7).

Konvensi Hukum Laut 1982 menerapkan "prinsip pembedaan" dalam menentukan lebar laut teritorial suatu negara sebagaimana dimaksudkan di atas, melalui penerapan ketiga cara penarikan garis pangkal untuk menentukan lebar laut teritorial, sehingga dapat mencerminkan adanya keadilan dalam masyarakat internasional. Bagi negara-negara dengan karakteristik kontinental dipergunakan garis pangkal biasa (normal baseline) untuk mengukur lebar laut teritorial, bagi negara-negara kontinental dengan karakteristik teluk yang lebar atau terdapat pulau-pulau di depan pantainya dipergunakan garis pangkal lurus (straight baseline) untuk mengukur lebar laut teritorialnya, sedangkan bagi negara-negara dengan karakteristik kepulauan dapat dipergunakan garis pangkal lurus kepulauan (archipelagic straight baseline) untuk mengukur lebar laut teritorial.

Ketiga, Undang-undang Nomor 6 Tahun 1996. Undang Undang Nomor 6 Tahun 1996 pada dasarnya merupakan produk hukum yang menggantikan Undang-undang Nomor 4/Prp/ 1060 mengenai Perairan Indonesia. UndangUndang Nomor 6 Tahun 1996 juga menganut prinsip pembedaan sebagaimana dalam UNCLOS 1982 yang telah menjadi Hukum Nasional Indonesai berdasarkan Undang-undang Nomor 17 Tahun 1985.

\section{Penutup \\ Simpulan}

Beranjak dari ulasan sebelumnya, dapatlah disimpulkan bahwa secara konstitusional telah terkandung prinsip-prinsip penyelenggaraan pemerintahan daerah dalam UUD 1945. Prinsip-prinsip dimaksud antara lain memberikan ruang bagi pengembangan daerah-daerah khusus dan istimewa (termasuk mempertimbangkan realitas geografis dan sosial sebagai daerah kepulauan), namun prinsip dimaksud belum dijabarkan secara tegas dan jelas dalam ketentuan UU No. 32 Tahun 2004. Demikian pula pengaturan dalam UU No. 32 Tahun 2004 menentukan pembagian kewenangan yang concurrent secara proporsional dengan mempertimbangkan asas ekternalitas, namun belum ada ketegasan mengenai kewajiban pemerintah untuk memfasilitasi penyelenggaraan pemerintahan di daerah-daerah kepulauan. Selain itu, perspektif akademik juga memberikan legitimasi terhadap satuan pemerintahan daerah yang bersifat khusus sebagai wujud dari desentralisasi asimetris. 


\section{Rekomendasi}

Berkaitan dengan upaya memperkuat status dan posisi daerah-daerah kepulauan, penulis merekomendasikan agar dalam merevisi UU No. 32 Tahun 2004 perlu mempertegas dan memperjelas pengaturan tentang daerah khusus dan daerah istimewa dengan memasukkan daerah kepulauan sebagai salah satu wujud pemerintahan daerah dimaksud serta mengatur hubungan pemerintah dengan pemerintah daerah secara khusus dalam hal intervensi terhadap daerah-daerah khusus dan istimewa dimaksud. Selain itu, revisi UU No. 32 Tahun 2004 juga harus mempertegas kewajiban pemerintah untuk memfasilitasi penyelenggaraan pemerintahan di daerah-daerah kepulauan.

\section{Daftar Pustaka}

Adimihardja, Kusnaka. "Kearifan Lokal Komunitas Adat Mengelola Sumber Agraria". J urnal Analisis Sosial. Vol. 6 No. 2. Juli 2001;

Badan Kerjasama Propinsi Kepulauan. 2009. Naskah Akademik Undang Undang Daerah Kepulauan. Jakarta: Badan Kerjasama Propinsi Kepulauan;

Chaidir, Ellyadar. "Manajemen Pembangunan Hukum di Daerah". Jurnal Mahkamah. Vol. 19 No. 2. Oktober 2007;

Dahuri, Rukmin. "Kerjasama Kelautan Dalam Menciptakan Stabilitas Kawasan". J urnal PASKAL. Vol. 1 No. 3. Oktober 2002. Jakarta: Pusat Kajian Strategis Kepentingan Nasional;

Fauzan, Muhammad. 2006. Hukum Pemerintahan Daerah, Kajian tentang Hubungan Keuangan Antara Pusat dan Daerah.
Yogyakarta: UII Press;

J uanita, Grace. "Pengaruh Kaidah Bukan Hukum Dalam Proses Pembentukan Kaidah Hukum", J urnal Hukum Pro J ustitia. Vol. 25 No. 2. April 2007. Bandung: FH Unpar;

Jaweng, Robert Endi. "Anomali Desentralisasi Asimetris". Suara Pembaruan. Selasa, 21 Desember 2010;

Laynurak, Yoseph M. "Analisis Model Optimalisasi Sumber Daya Pantai Terhadap Kesejahteraan Nelayan di Kabupaten Belu NTT", Flobamora Vol. No. 01. Tahun 2009. NTT: J urnal Litbang NTT;

Marzuki, H.M. Laica. "Membangun UndangUndang Yang Ideal". Jurnal Legislasi Indonesia. Vol. 4 No. 2. J uni 2007. Dirjen Hukum dan HAM;

Saleng, Abrar. "Implementasi Bentuk Negara Kesatuan Dalam Dalam Pengelolaan Sumber Daya Alam Dan Kekayaan Negara Dari Perspektif Otonomi Daerah". J urnal Hukum Yurisprudensia. Vol. 6 No. $1 \mathrm{~J}$ anuari 2007;

Santoso, M Agus. "Otonomi Daerah di Negara Kesatuan Republik Indonesia", Jurnal IImu Administrasi. Vol. VI No. 4. Desember 2009;

Siahaan, Maruarar. "Relevansi Penguasaan Negara atas Cabang Produksi Strategis Menurut UUD 1945". Jurnal Konstitusi, Vol. 4 No. 3. September 2007. J akarta: MKRI;

Stefanus, Kotan Y. “Mengembangkan Demokrasi Dalam Era Otonomi Daerah". J urnal Konstitusi. Vol. 2 No. 2. Nopember 2009. J akarta: MKRI;

Thamrin, Juni. "Menciptakan Ruang Baru Bagi Demokrasi Partisipatif: Dinamika dan Tantangan", J urnal Analisis Sosial. Vol. 9 No. 3. Desember 2004. 